\title{
Analysis of Patient Satisfaction and Interest of Patient on Doctor Servicing Health Care Provider in the Healthcare and Social Security Agency in Pesantren District Kediri
}

\author{
Sandu Siyoto (Author) \\ Institute of Health Science Surya Mitra Husada \\ Email : siyotos@yahoo.com
}

\author{
Elya Irawan Putri (Author) \\ Institute of Health Science Surya Mitra Husada
}

\begin{abstract}
Health services as health facilities for health service of first strata who responsible to carries out individual health efforts and society health efforts still minim. Good quality service will give satisfaction and interest on patient. This reseach purposed to analyze of patient satisfaction and interest of patient on doctor servicing health care provider in the healthcare and social security agency in Pesantren district Kediri. This research used analytical design and used cross-sectional methodhe approach. Population taken from patient who coming tho the doctors PPK 1. Samples is selected with technique sampling consecutive as many as 106 people. Instrument of research by using questionaire. There is two variable measured that is independent variable satisfacion and variable dependent interest of patient on doctor servicing PPK 1. Results of this research indicates that satisfaction with satisfied category as many as 41,5\% and interest of patient on doctor service PPK 1 category as very high $79,2 \%$. The results of cross tabulation of almost half of the patients were satisfied satisfaction can give patient interest on doctor servicing PPK 1 as many as 39,6\%. From test analysis ordinal regeresi got result of p-value $=0,000, \alpha$ $=0.05$, because result of significance smaller than significance level (0.05) means $\mathrm{HO}$ is refused, $\mathrm{H} 1$ is received. As for the indicator of the patient satisfaction are expertise of employee, responsiveness, guarantee, physical evidence and empathy. And an indicator of patient interest is interest treatment to back, give information to others, the first choice, saying positive thing and recommend to choose. By provide good service to the patient it will give interest to treatment back.
\end{abstract}

Keyword : Satisfaction, interest of patient on doctor servicing PPK 1

\section{INTRODUCTION}

In 21 century the state, we are faced by problems and challenges different from the previous period. Community demands for service quality of government officials need to get serious attention from government institutions, both at central and local levels (Hakim, 2010).A very important aspect in human life among others is health. Everyone did a variety of ways to obtain good health. A person suffering from pain will usually try to cope with and treat the disease until cured. Someone in achieving the expected recovery sometimes needs help from other parties in this case is the doctor's services PPK 1 , can be either general practitioners/family doctors, dentists, midwives, community health centers, balkesmas, or clinic. Doctors KDP 1 is one of the health professionals authorized to provide health services to the general public. This situation makes doctors need to pay attention to the services offered to consumers in this case is the patient who will use the services of doctors KDP 1 so that patient satisfaction with the services offered as in [1]. In the old paradigm known doctor is most dominant role. Doctors tend autonomous and autocratic. Other professions considered only serves to help the task of the physician. Patients are also not a lot of rights, and tend to be decided by just any doctor. In the new paradigm of development has changed. From the point of patient, this time costumer takes charge. Patients determine which products and services they need, which must be met by the manufacturer, in this case the doctor. Health law No.23 of 1992 has explicitly mentions "patients' rights" which includes the right to information, the right to give consent, the right to medical confidentiality and the right to a second opinion. In this Act also mentioned that health workers, including doctors KDP 1 course in performing its obligations required complying with professional standards and respecting the rights of patients.

Ref [1] BPJS (Social Security Agency) is a legal entity formed to administer social security programs (Act No. 24 of 2011). BPJS consists of BPJS Health and Employment. BPJS a legal entity set up to organize the health insurance program in the form of health protection for participants BPJS benefit health care and protection to meet the basic health needs are given to every person who pays dues or fees paid by the government as in [1]. Health services are generally rated by the 
community, especially about good health care received by the community, but in reality there are complaints, especially users BPJS of service provided to users BPJS because patient expectations do not match reality accepted causing the patient's perception BPJS to services has received poor and unsatisfactory.

Based on the data obtained by researchers on 21 October 2015 from the Health BPJS of Kediri, the number of health facilities of First Instance in Kediri cooperate with BPJS is as much as 44, which include 19 consists of General Practitioners, 7 Dentist, 9 health centers, 9 clinic (Health BPJS of Kediri, 2015). Environmental demands on the quality of services for patients, especially users BPJS, the necessary efforts to increase the quality of service by comparing the services expected by the service perceived by the public. The government as a policy authorization must immediately make efforts to improve the quality of service for users BPJS, so that these services can be provided benefits as much as possible and improve the health of Indonesian society in general and especially for the user community satisfaction.

\section{METHOD}

This study uses survey research design analytic cross sectional method as in [2]. The population is patients coming on physician services PPK 1. Samples were selected with consecutive sampling technique amounted to 106 people. The research instrument using questionnaires. There are two variables measured is the independent variable and the dependent variable interest satisfaction of patients on physician services PPK 1. The results were analyzed using ordinal regression test as in [3].

\section{RESULTS}

Characteristics of the subjects in this study included age, gender, occupation, education, number of visits, BPJS status, marital status, and level of satisfaction and interest of the patient. Based on data show that out of 106 respondents, almost half of respondents aged 41-60 years are 49 respondents or $46.20 \%$. Most are women, the number of 54 respondents or $50.94 \%$. Almost all of the respondents worked as an entrepreneur / businessman that 36 respondents or $33.96 \%$. High schools educated are a number of 63 respondents or $59.43 \%$. Nearly half of the older patients who have made visits to the doctor KDP 1 School District 3-4x that amount 48 respondents or $45.30 \%$. Most are independent participants that a number of 91 respondents or $85.85 \%$. Marital status (married) that a number of 86 respondents or $81.10 \%$. Most of the categories are satisfied a number of 44 respondents, or $41.5 \%$. Interests of patients after the service KDP 1 in Kediri City School District is mostly in the category of a very high number of 84 respondents, or $79.2 \%$.

From the results of ordinal regression statistical test is said to be $\mathrm{p}$ value $=0,000$ or $\mathrm{p}$ value $<\alpha(0.05)$ and $\mathrm{H} 1$ accepted meaning there is a patient satisfaction and interest on servicing physician health care providers 1 (PPK 1) in the program in the Social Security Agency School District Kediri.

\section{DISCUSSION}

Patient satisfaction with the services physician health care providers 1 (PPK 1) The School District of Kediri in the very satisfied category is $35.8 \%$ or 38 respondents, dissatisfied $41.5 \%$ or 44 respondents, dissatisfied $19.8 \%$ or 21 respondents were very dissatisfied and $2.8 \%$ or 3 respondents. From the data, shows that the vast majority of patients are satisfied after getting a medical service health care providers 1 (PPK 1) which is influenced by several factors, including, gender factor, the factor of the levels of education, age, occupation, number of visits, status BPJS and marital status, Satisfaction is an emotional response to the evaluation of the consumption experience a product or services above average as in [4]. According to researchers, a person's emotional maturity level is strongly influenced by a Person's maturity or age, as a person thinks, judging or evaluating the goods or services received. Patients are individuals who are directly involved in the procurement, use, and specify products and services including decision-making processes that precede and follow those actions as in [5]. In principle, customer satisfaction can be measured by a variety of methods and techniques. One method for measuring customer satisfaction is a complaint and suggestion system. Any organization that is oriented on the customer (customer oriented) should provide ample opportunity to its customers to submit suggestions, opinions and complaints they (Kotler, et al, 2006). Media that used to be a suggestion box are placed in places convenient (easily accessible or frequently bypassed the customer), the comment card (which can be filled directly or can be sent via mail to the company), a dedicated phone line is free and others

Satisfaction is the level of perceived state of a person that is the result of comparing the appearance or perceived product come out in conjunction with the hope someone as in [6]. One out come from the use of the customer experience is the satisfaction or uncertainty of the product or service. A customer assessment process can be positive or negative based on experience, satisfaction, or uncertain. If the increased patient satisfaction, the patient will have a willingness to come back to the clinic for the next inspection. A sense of satisfaction with the services provided in the clinic obtained through the direct experience of patients who have several times to get service comparing the expectations with the services provided by the outcome (the result of services, starting from the beginning to the end) obtained in the clinic.

\section{A. Doctor Patient Interests Top Employer Services Health Care 1 (PPK 1)}

The result shows that the interests of patients on medical service providers health 1 (PPK 1) The School District of Kediri, a large partially expressed very high amounting to between $81.1 \%$ or 86 respondents, while stating higher by $8.5 \%$ or 9 respondents, who claimed a low of $9.4 \%$ or 10 respondents stating very low at $0.9 \%$ or 1 respondent. Clarity in the interest of patients includes clarity of cognition, affection and konasi. Value are very high, high, low or extralow on Interests Patients on Care Physician Employer Health Care 1 (PPK 1) The School District of Kediri by respondents 
are influenced by various factors such as the level of education, age, occupation, status BPJS, marital status, gender, and number of visits. Satisfaction is the level of perceived state of a person that is the result of comparing the appearance or perceived product come out in conjunction with the hope someone as in [6]. One out come from the use of the customer experience is the satisfaction or uncertainty of the product or service. A customer assessment process can be positive or negative based on experience, satisfaction, or uncertain. If the increased patient satisfaction, the patient will have a willingness to come back to the clinic for the next inspection. A sense of satisfaction with the services provided in the clinic obtained through the direct experience of patients who have several times to get service comparing the expectations with the services provided by the outcome (the result of services, starting from the beginning to the end) obtained in the clinic.

\section{B. Doctor Patient Interests Top Employer Services Health Care 1 (PPK 1)}

From table 1 shows that the interests of patients on medical service providers health 1 (PPK 1) The School District of Kediri, a large partially expressed very high amounting to between $81.1 \%$ or 86 respondents, while stating higher by $8.5 \%$ or 9 respondents, who claimed a low of $9.4 \%$ or 10 respondents stating very low at $0.9 \%$ or 1 respondent.

Clarity in the interest of patients includes clarity of cognition, affection and konasi. Value are very high, high, low or extra-low on Interests Patients on Care Physician Employer Health Care 1 (PPK 1) The School District of Kediri by respondents are influenced by various factors such as the level of education, age, occupation, status BPJS, marital status, gender, and number of visits

Interest is high liver tendency towards something "passionate" desire. Interest is the attitude that makes people happy to be a specific object as in [7]. Meanwhile, according Azjen and Fisbein quoted in Egel et al (2007) of interest to be imaged with the analysis and subjective norms towards a certain object. Thus the interest of a person against a particular object is strongly influenced by the attitude. Attitude is a tendency to respond positively or negatively to people, objects or situations [8]. Between interests and attitudes strongly influenced by environmental stimuli, the stimulus was instrumental in guiding, encouraging and initiates a person to behave in certain ways. Ref [9] considers interest as relatively sedentary tendencies as any part of a person under on interest and pursue a particular field. The key elements in terms of interest, namely the lack of attention, the thrust of each individual and the pleasure (QYM, 2008). Characteristics of individuals with high interest by Purnama QYM (2008) describe the individual characteristics, namely: the existence of great concern, have high expectations, successoriented, have pride, willingness to try and have a positive balance.Interests of patients on medical service health care providers 1 (PPK 1) The School District of Kediri there are categorized as a low number of 10 respondents or $9.4 \%$ and very low at 1 respondents or $0.9 \%$. Based on the results of the questionnaire, there are three points lowest of the low and very low lies in disseminating information, make the first selection, and saying positive things.

Analysis of Patient Satisfaction with Interests From table 1 study showed that patients who are satisfied satisfaction can provide patient interest of $39.6 \%$ or some 42 respondents. Ordinal regression test results showed the $\mathrm{p}$ value $=0,000$ or $\mathrm{p}$ value $<\alpha(0.05)$ and $\mathrm{H} 1$ accepted meaning there is a Patient Satisfaction and Interest on Physician Services Employer Health Care 1 (PPK 1) Program at the Social Security Agency School District Kediri. Satisfaction is the level of perceived state of a person that is the result of comparing the appearance or perceived product come out in conjunction with the hope someone as in [6]. Satisfaction is an emotional response to an evaluation of the experience of consumption of a product or service above average as in [4]. Meanwhile, according to Ref [10] is the level of satisfaction of one's feelings after comparing the performance and results of the perceived (and perceived service received) with the expectation.

Thus there is harmony between satisfaction with the fact the field which is a form of excellent service that aims to improve quality of service, attention inadvertently born willfulness, interested taste, desire and pleasure, which ultimately determines the degree of specialization in the patient. An activity carried out not in accordance desire will produce less enjoyable achievements can be said that the fulfillment of a person's interest will get pleasure and inner satisfaction which can lead to motivation as in [11]. When satisfaction decreased the interest will also be decreased. So that interest will not be permanent, but interests are temporary or can be fickle and the satisfaction of patients satisfied with the services one would desire KDP doctor to visit again

\section{CONCLUSIONS}

Patient satisfaction at Kediri City School District has satisfied categories are a number of 44 respondents $(41.5 \%)$ of the total respondents were 106 respondents. 2. Interests of patients on medical service health care providers 1 (PPK 1) in Kediri City School District has a very high category as many as 84 respondents $(79.2 \%)$ of the total respondents were 106 respondents. 3. There is a relationship between satisfaction and interest of the patient on physician services health care providers 1 (PPK 1) the social security program organizing body in Kediri City School District.

\section{REFERENCES}

[1] "Undang-Undang No. 23 Tahun 2011 Tentang BPJS.," in UndangUndang No. 23 Tahun 2011 Tentang BPJS., 2011.

[2] A. H. Alimul, Riset Keperawatan dan Teknik Penulisan Ilmiah. Jakarta: Jakarta: SalembaMedika.

[3] Arikunto, Prosedur Penulisan Suatu Pendekatan Praktek.Edisi Revisi V. Jakarta: Rineka Cipta.

[4] Kuswadi, Cara Mengukur Kepuasan Karyawan. Jakarta: PT. Elex Media Komputindo Kelompok Gramedia.

[5] F. Tjiptono, .Manajemen Pemasaran. Yogyakarta: Penerbit Andi. Yogyakarta: Penerbit Andi. 
[6] Wijono D, Manajemen Mutu Pelayanan Kesehatan. surabaya: Airlangga University Press.

[7] Lukaman S, Pelayanan Prima. Jakarta: Lembaga Administrasi Negara Republik Indonesia.

[8] H. Rohman, Inovasi Program Dalam Optimalisasi Kinerja Pelayanan Publik . Public Administration Community.

[9] Palupi Widyastuti, Penjaminan Kualitas Dalam Keperawatan. Jakarta: EGC.

[10] P0han, Jaminan Mutu Layanan Kesehatan. Jakarta: EGC.
[11] R. M. Choudhry and D. Fang, "Why operatives engage in unsafe work behavior: Investigating factors on construction sites," vol. 46, no. 4, pp. 566-584, Apr. 2008. 